\title{
The European geological surveys and EuroGeoSurveys: roles and tasks in a supranational structure
}

\author{
Geological Survey of Spain, Ríos Rosas, 23, 28003 Madrid, Spain
}

European geological surveys often are or derive from old institutions, created in the XIX Century to deal with geological mapping and mineral resources but now also hydrogeological and geohazard studies. There are differences among countries and regions as to how responsibility is shared among concurring organisations for natural resources considered essential or of strategic value to a given country or region. In spite of this, there is common ground for geological surveys, in a series of roles and tasks in the earth sciences and technology field that can be dealt with in a more comprehensive framework. A wider vision shared by the geological surveys allows approaching and solving problems in a way that does not only interest the respective countries or regions but the whole set of them. This is the case of EuroGeoSurveys, the association of geological surveys of the current 15 members of the European Union plus Norway as an associate member. EuroGeoSurveys, as a voluntary association formed by state organizations but not officially representing their governments, is in the right position to help the European Union's institutions in earth science and technology-related affairs, to influence the preparation of directives of benefit to the community, and to cooperate in carrying out research and technological development projects both inside and outside the Union. These tasks can be carried out by the European geological surveys together, through EuroGeoSurveys, or individually, or in cooperation with other geological surveys. This paper comments on the Subsidiarity Principle, which regulates the relationships between the European Union Commission and the member states, and on how this principle affects the European geological surveys and EuroGeoSurveys.

\section{Introduction}

The long history of geological investigation and development in geological surveys in almost all European countries, former nations, and some regions, has resulted in knowledge of great value in geology, geological mapping, hydrogeology, mining engineering, exploration, evaluation and management of mineral and water resources, geohazards science and technology, geodata and geoinformation gathering and processing, and more recently in geoenvironmental sciences and engineering. Thus the European Union has the opportunity to profit from this enormous potential for its own benefit and make it available to developing countries. Table 1 shows the year of foundation of the European Union's geological surveys and of some other countries older than 100 years. Further information can ben found in Socolow and Fakunding (1994), Otto (1995), and Price (1992).

Table 1 Year of foundation of the European Union's geological surveys and the geological surveys (or equivalent or antecedent institutions) of other countries. Data from Findlay (1997); Annells (1996, 1998); FOREGS (internal report prepared by BRGM).

\begin{tabular}{|c|c|c|c|}
\hline \multicolumn{2}{|c|}{ European Union } & \multicolumn{2}{|c|}{ Other countries } \\
\hline Country & $\begin{array}{c}\text { Year of } \\
\text { foundation }\end{array}$ & Country & $\begin{array}{c}\text { Year of } \\
\text { foundation }\end{array}$ \\
\hline United Kingdon & 1835 & & \\
\hline Ireland & 1845 & & \\
\hline Austria & 1849 & North Carolina (USA) & 1823 \\
\hline Spain & 1849 & Tennessee (USA) & 1831 \\
\hline Germany & 1850 & Canada & 1842 \\
\hline Norway $(*)$ & 1858 & India & 1851 \\
\hline Portugal & 1858 & New South Wells (Australia) & 1852 \\
\hline Sweden & 1858 & Newfoundland (Canada) & 1864 \\
\hline Italy & 1867 & Hungary & 1869 \\
\hline France & 1868 & Switzerland (Hydr. Surv.) & 1872 \\
\hline Prussia (Germany) & 1873 & Queensland (Australia) & 1877 \\
\hline Finland & 1885 & United States of America & 1879 \\
\hline Denmark & 1888 & Japan & 1882 \\
\hline Belgium & 1896 & Egypt & 1896 \\
\hline Netherlands & 1903 & & \\
\hline Luxembourg & 1936 & & \\
\hline Greece & 1952 & & \\
\hline
\end{tabular}

* Associated Country

Earth science and technology-related topics exist everywhere in real life and have to be addressed by politicians, officials of public administrations and managers. But there is a gap between geoexperts and geoscientists on one side and many administrators, decision makers, and managers on the other. This gap has to be filled, and communication has to be enhanced, and understanding of the barriers in between diminished, at all levels, but especially at high ranks in the European Union and the member states, where legislation is produced and decisions are taken. This is an essential task for geological surveys.

The creation of EuroGeoSurveys in 1995, as a voluntary Association of the European Union's geological surveys (Annells, 1996), is an important step ahead and also a means to inform citizens and to disseminate basic knowledge. 


\section{The European Union's geological surveys and their role}

The actual responsibilities of the different European geological surveys or institutes vary from country to country depending on their own administrative characteristics and the sharing of duties with other organisations. A typical evolution is moving the emphasis from exploration and promotional activities to attract investment, to data bases and, recently to environmental activities (Findlay, 1997). This has gone along with cutbacks of staff and budget, and the tendency to get financial complements from external sources. But earth sciences and technology are the common background, from mapping to mathematical modelling of geology-related processes. The major issues underpining this background are:

- Studies and mapping in geology and in related fields, such as geophysics, geochemistry, and palaeontology, mostly on the continent but also on the marine platform and the sea floor.

- Natural resources studies, evaluation and development, with special commitment to minerals and rocks, but also to coal, oil, and heat from the Earth, including radioactive substances.

- Mining technology and mineral-extraction engineering.

- Hydrogeology and groundwater resources, including the role of groundwater in internal and external geological processes. Mineral and thermal waters are special common topics. Aquifer protection and remediation are emerging fields of interest, as well as geo- logical confinement of wastes and other substances in low permeability-formations.

- Geological hazard studies and risk assessment, which commonly include those of landslides, subsidence, ground collapse, volcanism, droughts, floods, and avalanches. Earthquake and seismicity studies and surveys are often shared with other institutions.

- Geoenvironment, an emerging and fast developing field, which includes the study and remediation of contaminated soil, environmental-impact studies of major public works, mining projects and energy-production facilities, and the effects of growing urban areas. They include also water and soil-related studies of wetlands, arid zones, and desertification.

- Geological data-information systems and documentation centres, including lithotecs and museums, as well as publishing and disseminating series, documents, posters, and leaflets, either in printed form or as informatic products.

The importance of groundwater and water resources in general explains why in some cases their study is given to a specialised body, different from the geological survey. Oil and radioactive minerals, and in some cases coal, may follow a similar scheme. But in all these cases, the wider and more comprehensive vision of a geological survey may be lost. Consequently the results may be biased or miss some essential points if effective cooperation is not secured.

Geological surveys are public entities. Their administrative structure, competence, funding, and capacity to get external economic resources to carry out their duties and to work under contract vary, however, from country to country and change with time (Find-

Table 2 Total staff, \% of financing from public sources, area covered per permanent staff person, $10^{3}$ inhabitants per permanent staff person, budget as permil gross domestic product and $10^{3}$ euros spent per staff person (rounded and assumed figures for 1995 -97, interpreted from the 1998 FOREGS internal report prepared by BRGM).

\begin{tabular}{|c|c|c|c|c|c|c|}
\hline Country & $\begin{array}{r}\text { Total } \\
\text { staff }\end{array}$ & $\begin{array}{l}\text { Finances, } \\
\text { \% public }\end{array}$ & $\mathrm{km}^{2} / \mathrm{staff}$ & $\begin{array}{c}10^{3} \text { inh/ } \\
\text { staff }\end{array}$ & $\begin{array}{l}10^{3} \text { budget/ } \\
\text { GDP }\end{array}$ & $\begin{array}{c}10^{3} \text { euros/ } \\
\text { staff }\end{array}$ \\
\hline \multicolumn{7}{|l|}{ European Union } \\
\hline Austria & 125 & 94 & 1000 & 100 & 40 & 80 \\
\hline Belgium & 40 & 100 & 1000 & 350 & 10 & 80 \\
\hline Denmark & 250 & 72 & 180 & 22 & 100 & 70 \\
\hline Denmark+Greenland & 400 & 77 & 1100 & 15 & 200 & 80 \\
\hline Finland & 830 & 96 & 490 & 8 & 40 & 58 \\
\hline France & 915 & 40 & 600 & 64 & 10 & 100 \\
\hline Germany (BGR) & 890 & 97 & 145 & 33 & 10 & 63 \\
\hline Germany (Länder) & 1650 & 100 & - & - & - & - \\
\hline Greece & 1050 & 80 & 125 & 10 & 300 & 30 \\
\hline Ireland & 50 & 96 & 1400 & 72 & 50 & 60 \\
\hline Italy & 70 & 100 & 4500 & 860 & 10 & 120 \\
\hline Luxemburg & 7 & 100 & 650 & 85 & 10 & 22 \\
\hline Netherlands & 360 & 70 & 101 & 50 & 40 & 90 \\
\hline Norway (Assoc.) & 230 & 75 & 1580 & 21 & 100 & 76 \\
\hline Portugal & 360 & 50 & 280 & 30 & 100 & 36 \\
\hline Spain & 420 & 80 & 1200 & 100 & 40 & 50 \\
\hline Sweden & 250 & 80 & 1900 & 36 & 80 & 70 \\
\hline United Kingdom & 810 & 65 & 315 & 76 & 40 & 65 \\
\hline \multicolumn{7}{|l|}{ Others (FOREGS) } \\
\hline Albania & 1000 & 100 & 29 & 4 & $\sim$ & $\sim 1$ \\
\hline Bulgaria & - & - & - & - & 1000 & - \\
\hline Cyprus & 115 & 100 & 80 & 6 & - & 35 \\
\hline Czech & 310 & 85 & 250 & 32 & 500 & 11 \\
\hline Estonia & 160 & 80 & 330 & 10 & 100 & 6 \\
\hline Hungary & 150 & 30 & 640 & 70 & 200 & 22 \\
\hline Iceland & 90 & 44 & 1145 & 3 & 10 & 60 \\
\hline Lithuania & 120 & 87 & 557 & 32 & 800 & 12 \\
\hline Poland & 810 & 25 & 380 & 45 & 200 & 24 \\
\hline Romania & 525 & 85 & 450 & 43 & 200 & 10 \\
\hline Slovakia & 385 & 90 & 130 & 14 & 200 & 3 \\
\hline Slovenia & 145 & 25 & 150 & 14 & 70 & 3 \\
\hline Switzerland & 390 & 100 & 580 & 100 & 30 & 100 \\
\hline Turkey & 5000 & 91 & 165 & 13 & 300 & 9 \\
\hline
\end{tabular}


lay, 1997; Cook, 1994; Otto, 1995). Table 2 and 3 are shown for some statistical information and the departmental adscription. Generally, direct administrative and management responsibilities are small or have been fully given to other entities, although in the past some surveys have played a significant role in administrative and managerial affairs. The current trend is to become institutions to create an infrastructure of knowledge and to carry out oriented research. It is not easy to make this compatible with the administrative and managerial affairs and responsibilities. The balance between creating an infrastructure of knowledge (public good) and research is delicate. If the first task dominates, the incentives and opportunities provided for research are partly lost, and if the second task dominates the first one may be diluted.

Common main objectives are carrying out geology and geoscience-related national plans (geological mapping, hydrogeological mapping, geohazards mapping, inventory of mineral and water resources, cataloging mining activities, etc.), research and technological development (RTD) activities, territorial studies, infrastructural land and water surveys, specialized exploratory drilling, data gathering, information processing and dissemination of geoscientific issues, and coordinating the geological activities of other institutions. These tasks are of structural value to society and essential to sustain and improve human life (Cook, 1997). A discussion on the value of geological maps can be found in Bernknopf et al. (1993).

Actual research institutions and university geology departments carry out intensive and effective activities and may become the scientific and technological leaders in certain aspects of the geological sciences. This is fully compatible with the tasks of geological surveys, which have broader interests, more territorial and more directly applied in many aspects, although strict scientific issues must also be considered. There is often close collaboration among them and also agreements for fruitful joint ventures. But commonly the geological survey is the national or regional body in charge of mapping and publishing and disseminating knowledge and information, and often it carries out a coordinating role. Thus, the Commissions of the International Union of Geologial Sciences are often linked to corresponding national geological surveys.

Table 4 shows a list of possible tasks of Geological Surveys and how many of them are actually included in the activities of 30 European countries, including all those in EuroGeoSurveys.

Table 3 Departmental description of European and European Union's geological surveys in 1998 (after FOREGS). The trend indicates recent changes.

\begin{tabular}{llccccc}
\hline $\begin{array}{l}\text { Government's } \\
\text { Department }\end{array}$ & $\begin{array}{l}\text { Environ- Industry } \\
\text { ment }\end{array}$ & $\begin{array}{l}\text { Science \& Economy } \\
\text { Technology }\end{array}$ & $\begin{array}{l}\text { Public Others } \\
\text { Works }\end{array}$ \\
\hline $\begin{array}{l}\text { Number of } \\
\text { countries (29) }\end{array}$ & 9 & 5 & 5 & 5 & 2 & 3 \\
$\begin{array}{l}\text { Number of EU } \\
\text { countries (16) }\end{array}$ & 2 & 3 & 3 & 4 & 2 & 2 \\
$\begin{array}{l}\text { Trend } \\
\text { (Increas- Decreas- } \\
\text { ing) }\end{array}$ & ing & $\begin{array}{c}\text { (Increas- } \\
\text { ing) }\end{array}$ & $\begin{array}{c}\text { Increas- } \\
\text { ing }\end{array}$ & $\begin{array}{c}\text { Decreas- - } \\
\text { ing }\end{array}$ \\
\hline
\end{tabular}

* Including Norway

\section{EuroGeoSurveys: its role}

EuroGeoSurveys is a non-profit association founded in 1995 by the geological surveys or institutes of the European Union, plus Norway as one of the union's associated countries. It is registered in France. The headquarters are in Brussels, where a Secretary General carries out the tasks set by the Board of Directors (Presidents) of the different geological gurveys. For the closer follow up there is a four-member Executive Committee, who are also members of the Council of Directors and change each year, according to the by-laws (Figure 1).

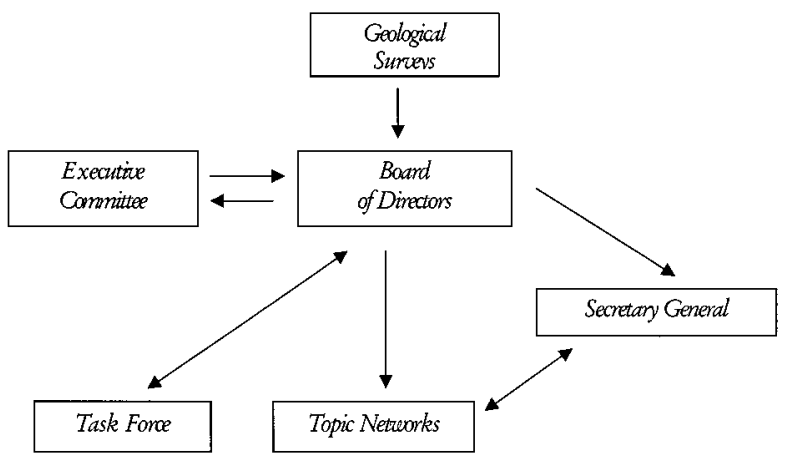

Figure 1 Organisation of EuroGeoSurveys.

Table 4 Possible tasks of geological surveys and their actual inclusion among the activities of 30 of the European geological surveys (after FOREGS 1998). N/30 means that $N$ countries out of the 30 carry out the task. The trend (last column) in brackets means that it is not clear.

\begin{tabular}{|c|c|c|c|}
\hline Task & & Com & $\overline{\text { ments }}$ \\
\hline Basic geology & All & $30 / 30$ & Stable \\
\hline Geological mapping & All & $29 / 30$ & Stable \\
\hline Hydrogeology & All & $30 / 30$ & Increasing \\
\hline Hydrology & Rare & $4 / 30$ & - \\
\hline Engineering geology & All & $27 / 30$ & Increasing \\
\hline Environment: natural hazards & All & $28 / 30$ & Increasing \\
\hline Environment: pollution & Common & $23 / 30$ & Increasing \\
\hline Environment: non hazardous wastes & Common & $20 / 30$ & (Increasing) \\
\hline Environment: hazardous wastes & Common & $21 / 30$ & Stable \\
\hline Environment: radioactive wastes & Common & $18 / 30$ & Stable \\
\hline Underground storage & Common & $16 / 30$ & Stable \\
\hline Metalliferous deposits & Common & $24 / 30$ & Decreasing \\
\hline Industrial and construction minerals & All & $26 / 30$ & Stable \\
\hline Energy: solid fuels & Common & $21 / 30$ & Stable \\
\hline Energy: hydrocarbons & Common & $16 / 30$ & (Increasing) \\
\hline Energy: nuclear & Some & $10 / 30$ & (Decreasing) \\
\hline Energy geothermal & Common & $23 / 30$ & (Increasing) \\
\hline Marine geology: open sea & Some & $6 / 30$ & - \\
\hline Marine geology: continental shelf & Common & $19 / 30$ & (Increasing) \\
\hline Geophysics & All & $27 / 30$ & (Increasing) \\
\hline Geochemistry & All & $27 / 30$ & (Increasing) \\
\hline Remote sensing & Common & $23 / 30$ & Stable \\
\hline Official geological information supply & ly All & $28 / 30$ & Increasing \\
\hline Permits delivery & Some & $6 / 30$ & - \\
\hline Soil science & Some & $10 / 30$ & - \\
\hline International activities & All & $28 / 30$ & Increasing \\
\hline Glaciology & Rare & $2 / 30$ & - \\
\hline
\end{tabular}

A main goal of EuroGeoSurveys is being the common representative body to all European geological surveys (Annells, 1996) before the European Union, mainly the Parliament, the different general directions of the Commission and some specialised agencies such as the European Environmental Agency. Each geological survey contribution is based in its deep knowledge, experience, national capabilities and information sources, and the freedom resulting from being a non profit public body. The added benefit of EuroGeoSurveys is the synergy of coordinating the large capabilities for: basis.

- Addressing geoscience issues on a transnational European

- Assessing the European Parliament, Commission, and other organisations in geoscientific matters to better accomplish their tasks and the implementation of directives.

- Contributing real data and good knowledge, acting without the constraints of administrative bodies or companies.

- Carrying out European projects as partners and associates, with the benefit of the large number or countries, the extensive back- 
ground and support the different national (and also regional) geological surveys may contribute.

- Assisting the European Union to obtain technical advice and information from the member countries of the Association,

- Collaborating in the transfer and dissemination of European knowledge and the outcome of projects, and in the study of the results of activities and regulations.

- Helping the European Union to carry out its policies and investments in other countries, especially the developing world and the close regions of eastern Europe and northern Africa. Some EuroGeoSurveys members have easy relationships with such countries as a result of deep cultural and linguistic links or trade and business infrastructures developed in the past. Such is the case for Spain (mostly in America), France (mostly in Africa), Portugal (mostly in Africa and Brazil), and the United Kingdom (mostly in Africa and Asia).

Thus, common topics of interest in RTD and other studies are related to policies on:

- Mining (metallic ores, industrial minerals and rocks, building materials, oil, gas, coal, uranium).

- Groundwater (exploration, exploitation, protection and management, wetland preservation, geothermics, mineral waters).

- Geoenvironmental issues (polluted soil, geological confinement, waste management).

- Geohazards (risk assessment, prevention, early warning, risk insurance).

- Urban environment (aquifer recharge changes, water-table modification, pollution of groundwater resources, peri-urban water supply, waste management).

- Rural environment and agriculture (small town water supply, impact of crops and irrigation on groundwater, treated sewage water application, cattle and animal waste, safe use of agrochemicals, forest impact on recharge).

- Industrial activities (soil and groundwater contamination, environmental impact, waste management).

- Transportation (impact on natural resources, pollution, protection areas).

- Consumer rights and information.

- International activities.

As well as:

- Geological, hydrogeological and other geoscientific mapping, at transnational level.

- Metadata, data banks, and sources of information of interest to the Union.

- Geological inheritance of Europe.

EuroGeoSurveys undertake those activities that lie clearly in the public interest and refer to public management. They benefit from the combined and coordinated expertise of its members in the direct interest of the European Union at large.

The members of EuroGeoSurveys are also members of the larger FOREGS group (Forum of the European Geological Surveys), founded earlier, and which links the Geological Surveys of the OCED's European countries. Whilst EuroGeoSurveys has a formal structure and an office in Brussels, and definite goals with respect to the European Union organisations (mainly the Parliament, the Commision, and the Council), FOREGS is more loosely organised and its goals are less focused.

\section{Taking into account the subsidiarity principle}

The goal of the subsidiarity principle is selecting the right level to implement decisions. This is a non-well defined, open concept, that has been introduced in the European Union Treaty after some years of evolution (Areilza, 1996).

The concept of subsidiarity was called for, without using the term, in Vatican papers dealing with state and church relationships.
It is a key element in the state and regions (Länder) relationships in Germany.

The simpler formulation of the subsidiarity principle states that an organisation or administration should not do what can be efficiently carried out at a lower level. Thus, when dealing with activities outside its exclusive competence, the European Union should only intervene when the objectives being considered will not be effectively accomplished by the state members, and would be more attainable at the community level due to their magnitude or the broad effects of the action being considered (Table 5).

\section{Table 5 The subsidiarity principle.}

\begin{tabular}{|c|c|}
\hline Goal : & $\begin{array}{l}\text { selecting the right level to implement decisions } \\
\text { open }\end{array}$ \\
\hline Characterist & : concept which is $\begin{array}{c}\text { not well defined } \\
\text { evolving }\end{array}$ \\
\hline Formulation: & $\begin{array}{l}\text { an organization should not do what can be } \\
\text { efficiently carried out at a lower level }\end{array}$ \\
\hline Action: & upwards and downwards \\
\hline Contents: & matters outside exclusive competence \\
\hline Application: & $\begin{array}{l}\text { European Union versus state members. } \\
\text { Not necessarily inside each state }\end{array}$ \\
\hline
\end{tabular}

The subsidiarity principle implies a minimum interference of powers. It tries to limit the centralisation of decision-making capacity and looks for flexibility in the sharing of powers in a vertical distribution of competencies. The trend is towards general scope and framework directives from the Union, to be then developed by the member states, thus preserving national instruments in areas which are not the exclusive competence of the Union. National action (or inaction) is assumed to be more effective, closer to the citizens, and more politically supported by the people. But a central power is needed to solve the externalities that are not internalised by those who cause them. The openess of the subsidiarity concept allows movement of the emphasis upwards or downward, depending on the moment, circumstances, and political arrangements. This is both its strength and its weakness.

In the framework of the European Union, the application of the subsidiarity principle is restricted to the relationships between Union's institutions and state members. The same principle can be applied to regulate the relationships among states and their regions, and among the regions and their municipalities, or any other dependency existing in the organisation of each state. Each state member decides how its executive powers are applied inside its territory. Then, the subsidiarity principle may or may not be applied inside the state and, if applied, it does not have to be shaped in the same way as it does in the European Union.

Accordingly there are political and administrative situations which range from fully centralised to federal (Germany is a good federal example), with intermediate forms, such as the autonomous regional governments of Spain. This certainly conditions the competencies and fields of action of states' geological surveys with respect to regional geological surveys, when they exist.

\section{The tasks of the geological surveys under the subsidiarity principle}

The tasks assigned to the geological survey of each European state are variable. In some cases the geological survey has the full responsibility to carry out its role at state level and other organisations are dependent on or coordinated by it, except for scientific research, which is often carried out, at least in part, under university departments or research council policies and rules. But in other cases, land planning and management is the subject of another state's regional administrations, such as the Länder in Germany or the Autonomies in Spain. This last model seems adequate for relatively large coun- 
tries looking for a greater efficiency in the state's tasks and administrative policies within political frameworks that vary from federal to decentralized in order to be closer to the areas in which the tasks have to be carried out or to local authorities. The political history of a given country is important in this respect. Germany comes from a federation of states which have given part of their sovereignty to the federation. This gives way to a geological survey's organization different from that in countries that have moved from a centralised system to a regional one, in which there is no sovereignty to be handed over by the regions (except for historical claims of powers which were long ago taken by the state) but a transfer of power from the state, as in Spain. The Spanish regional system is intermediate between federal and decentralized. All this explains that a general discussion of the tasks of geological surveys under the subsidiarity principle is not possible and the issues have to be analysed state by state.

In each territory (land, region, etc.) the management of some land and natural-resource issues can also be the responsibility of lower level organisations, such as the municipalities or associations of municipalities (as is the case of Spain and Portugal for town water supply and sewage).

Most geological surveys play the role of national geoinformation centres. This information is essential both at lower and higher territorial levels. The surveys coordinate information and data from lower levels, organise them, and convey them to higher levels.

Thus state's geological surveys play a significant role with respect to lower rank management organisations, which may hold full competence for natural resources, mines, water and geohazard administration and management. Partial transfer of powers and shared responsibilities, with different degrees according to the particular subject, allow the state to retain some direct control. This situation may lead to uncertainty of responsibility in cases of serious conflict, especially when political differences appear to be involved. In any case, conflicting situations in which major incidents are involved are benchmark cases for testing how the subsidiarity principle is applied in order to facilitate management in the best interests of citizens and the environment.

\section{The role of EuroGeoSurveys under the subsidiarity principle}

There are many activities that EuroGeoSurveys can and should carry out on behalf its members and the benefit of European citizens and under the principle of subsidiarity. Some of these goals are:

\section{Political goals}

- to be recognised as an European representative body, expert on applied earth sciences, before the European Union in order to provide the Union with targeted advice and assessment in the formulation of policies in fields such as mineral, water, energy, and soil resources, environmental quality, contamination, geohazards, and waste disposal.

- to facilitate links and joint ventures with geological surveys of countries outside the European Union and its associates in order to help in the foreign policies of the Union in issues related to geological surveys' tasks. This is the case of the other countries of FOREGS and may become with the ASGMI (Asociación de Servicios Geológicos y Mineros Iberoamericanos, Association of Ibero-American Geological and Mining Surveys), which include Spain and Portugal as founders and full members. The exchange of experiences is always at stake, as shown by the creation in 1994 of the International Consortium of Geological Surveys, ICOGS (Findlay, 1994).

\section{Technical goals}

- to be a permanent link between the European Union and the different national geological surveys in subjects of common interest,

- to be the source of the selected and synthetic geoinformation the European Union needs for high-level management,

- to coordinate multinational projects interesting to, or founded by, the European Union.

EuroGeoSurveys can become a natural path for channelling selected and synthetic geoinformation to the European Union, which is needed for high-level management under the subsidiarity principle. But this is something the different governments have to agree upon and create the needed links for. In fact some of the geological surveys are already feeding the European Environmental Agency's EIONET system which puts together information on the Union's environment to help high-level decision making.

EuroGeoSurveys is well positioned for the production of European information data sets on minerals, rocks, groundwater, geohazards, etc., as well as for follow up on applications corresponding to topics that otherwise lie in the geological survey's field of competency. Their independence, scientific profile, good connexions and weak administrative responsibilities are a great advantage. Some information, of course, may be not accord fully with official data or figures that come from administrative and management agencies. Then care must be taken and due official recognition of data sources is needed to avoid national and regional misunderstandings or confrontation. A clear benefit of this possible task of EuroGeoSurveys is helping to collect and make available on a national basis information which is often in dispersed and highly diverse national, regional, and even local data banks, and to make comparable across boundaries.

It is also important to state what are the clear limits to EuroGeoSurveys activities.

EuroGeosurveys, as an Association and according to its bylaws, has no administrative or management role, and its goals are only those outlined before. Its activity is carried out on a voluntary basis and adapted to what the European Union considers to be its own role according to the subsidiarity principle.

It has not been considered a role of EuroGeoSurveys to promote and finance by itself, that is, with funds provided by the members, joint projects or activities. These have to be carried out with European funds and Survey's contributions, according to the different national interests and possibilities, in the framework of their respective goals and competencies.

EuroGeoSurveys has not received specific competencies from its member states. This can be only accomplished through the creation of an European administrative body with governmental participation. This is far away from EuroGeoSurveys, which has no mandates from the countries involved. It is a non-govermental organization formed by govermental institutes.

Accordingly, EuroGeoSurveys has no legal nor administrative capacity to intervene by itself in transnational affairs related to mining, water resources, geohazards, etc. These are intergovernmental affairs, and not always even European Union affairs.

\section{Acknowledgements}

The author acknowledges the comments and suggestions contributed by the staff of the Geological Survey of Spain, mainly Drs. Luis Delgado, Manuel Regueiro, José Trigueros and Ángel García Cortés, but the ideas are the author's own, and they do not necessarily coincide with those of the Geological Survey of Spain (Instituto Tecnológico Geominero de España) and the Spanish Administration. This paper is a contribution to the 150th Anniversary of the Geological Survey of Spain and was presented in 1998, in a different format, during the celebration of the 125th Anniversary of the Prussian Geological Survey, in Hannover. 


\section{References}

Annells, R., 1996, EuroGeoSurveys: the national geological surveys combine to map a way forward for the total environment of the European Union: Episodes v. 19, no. 3, pp. 61-65.

Areilza, J.M.de, 1996, El principio de subsidiariedad en la construcción de la Unión Europea (The subsidiarity principle in the construction of the European Union). Fundación para el Análisis y los Estudios Sociales, Madrid: Papeles de la Fundación 29, pp. 1-82.

Bernkonoff, R.L., Brookshire, D.S., Soller, D.R. Mckee, M.J., Sutter, J.F., Matti, J.C. Campbell, R.H., 1993, Societal value of geologic maps: USGS. Circular 1111, Reston, Va.

Cook, P.J., 1994, The role of the geological surveys in the 21st century: Episodes, v.17, no.4, pp. 106-110.

Cook, P.J., 1997, The role of the earth sciences in maintaining our life-support system: British Geological Survey Technical Report WQ/97/1, pp. $1-17$.

Findlay, D.C., Reedman, A.J., Schalke, H.S.W.G., 1994, The International Consortium of Geological Surveys (ICOGS): a progress report: Episodes, v.17, no.4, pp. 115-117.

Findlay, C., 1997, National geological surveys and the winds of change: Nature \& Resources.v. 33, no.2, pp. 18-25.

Otto,J.M., 1995, National Geological Surveys. Resources Policy, v. 21, no.1, pp. 27-35.

Price, R.A., 1992, National Geological Surveys: their present and future roles: Episodes, v.15, no.2, pp. 98-100

Socolow, A.A., Fakunding, R.H., 1994, State Geological Surveys of the United States of America: history and role in State Government. National Geological Survey in the 21st Century, Misc. Rep.55: Geological Surveys of Canada, Ottawa, pp. 53-56.
Emilio Custodio received his $P h D$ degree from Polytechnical University of Catalonia, is a full professor of hydrogeology at the same University and currently is at leave as Director General of the Geological Survey of Spain (ITGE). His researches concentrate mostly on groundwater resources, hydrogeochemistry, environmental isotopes, coastal aquifers and groundwater behaviour. He is correspondent member of the Spanish Academy of Sciences and is a member of the Council of the International Association of Hydrogeologists.

Hydrogeologists.

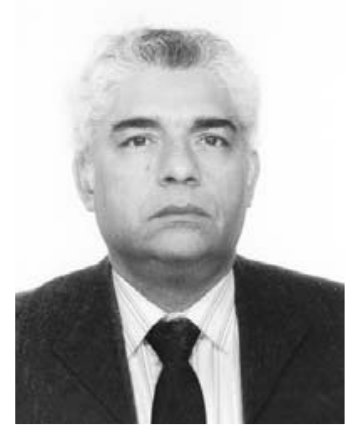

\title{
Meteorites and Their Parent Planets
}

Thoroughly revised second edition

\author{
by Harry Y. McSween, Jr. \\ 15th April 1999 \\ ISBN 0521587514 (paperback) \\ $£ 16.95$ (US $\$ 29.95$ ) \\ ISBN 0521583039 (hardback) \\ $£ 45.00$ (US\$74.95)
}

The book provides an engrossing overview of a highly interdisciplinary field - the study of extraterrestrial materials. The second edition of this successful book has been thoroughly revised, and describes the nature of meteorites, where they come from, and how they get to Earth. Meteorites offer important insights into processes in stars and in interstellar regions, the birth of our solar system, the formation and evolution of planets and smaller bodies, and the origin of life. Harry McSween's writing is accessible to scientists and nonscientists alike. He gives equal emphasis to the meteorites themselves and to what has been learned about the asteroids, comets, and planets from which they were derived.

The first edition was immensely popular with meteorite collectors, scientists and science students in many fields, and amateur astronomers. In this second edition all the illustrations have been updated and improved, many sections have been expanded and modified based on discoveries in the past decade, and a new final chapter on the importance of meteorites has been added. Everyone with an interest in meteorites will want a copy of this book.

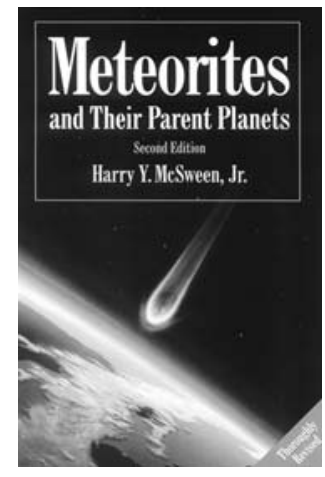

